\title{
Lung Cancer Patient Description in Immanuel Hospital Bandung from January 2013 to December 2014
}

\author{
Ida A.K.T. Bulan, Hana Ratnawati, Teresa L. Wargasetia \\ *Faculty of Medicine Maranatha Christian University \\ **Histology Department Faculty of Medicine Maranatha Christian University \\ ***BiologyDepartment Faculty of MedicineMaranatha Christian University \\ Jl. Prof. Drg. Suria Sumantri MPH No. 65 Bandung 40164 Indonesia \\ Email:trisnabulaan@gmail.com
}

\begin{abstract}
Lung cancer is a disease which has high incidence and mortality rate. It makes lung cancer become one of the biggest public health problems. The aim of this study is to find out the description of lung cancer patients in Immanuel Hospital Bandung from January 2013 to December 2014 based on the prevalence, gender, age, clinical features, metastasis, and mortality percentage. The method design was a descriptive retrospective method with data retrieval and collection of patient medical records that have been diagnosed with lung cancer in Immanuel Hospital Bandung from January 2013 to December 2014 period. This study showed that lung cancer prevalence was 51 patients, the majority of patients were males compared to females with the ratio of 2.7:1, the most common age group was 61-70 years old, the most common clinical features were dyspnea and cough, the most common site of metastasis was liver, and the mortality percentage was $33.33 \%$.
\end{abstract}

Keywords: Immanuel hospital Bandung, lung cancer, patient's description 


\title{
Gambaran Pasien Kanker Paru di Rumah Sakit Immanuel Bandung Periode Januari 2013 hingga Desember 2014
}

\author{
Ida A.K.T. Bulan, Hana Ratnawati, Teresa L. Wargasetia \\ *Fakultas Kedokteran Universitas Kristen Maranatha \\ **Bagian Histologi Fakultas Kedokteran Universitas Kristen Maranatha \\ ****Bagian Biologi Fakultas Kedokteran Universitas Kristen Maranatha \\ J1. Prof. Drg. Suria Sumantri MPH No. 65 Bandung 40164 Indonesia \\ Email : trisnabulaan@gmail.com
}

\begin{abstract}
Abstrak
Kanker paru merupakan penyakit dengan insidensi dan angka mortalitas yang tinggi. Hal ini menjadikan kanker paru sebagai salah satu masalah kesehatan yang besar di masyarakat. Penelitian ini bertujuan untuk mengetahui gambaran pasien kanker paru di Rumah Sakit Immanuel Bandung periode Januari 2013 hingga Desember 2014 berdasarkan prevalensi, jenis kelamin, usia, gejala klinik, metastasis, dan persentase kematian. Metode penelitian menggunakan metode deskriptif retrospektif dengan pengambilan dan pengumpulan data pasien yang didiagnosis kanker paru dari bagian rekam medik Rumah Sakit Immanuel Bandung periode Januari 2013 hingga Desember 2014. Penelitian ini menampilkan gambaran pasien kanker paru dengan prevalensi sebesar 51 pasien, jenis kelamin laki-laki lebih banyak dibandingkan perempuan dengan rasio 2,7:1, kelompok usia tersering yaitu 61-70 tahun, dengan gejala klinik tersering adalah sesak napas dan batuk, metastasis tersering yaitu ke organ hepar, dan persentase kematian adalah sebesar 33,33\%.
\end{abstract}

Kata kunci: gambaran pasien, kanker paru, Rumah Sakit Immanuel Bandung 


\section{Research Article}

\section{Pendahuluan}

Kanker paru merupakan kanker yang paling sering ditemui di seluruh dunia, dengan estimasi insidensi 1,8 juta kasus baru pada tahun 2012 atau 12,9\% dari total kasus kanker di seluruh dunia, dengan 58\% kanker paru terjadi di negara berkembang. ${ }^{1}$ Sekitar 221.200 kasus baru kanker paru terdiagnosis di Indonesia pada tahun 2015, dengan persentase $13 \%$ dari seluruh jumlah kanker di seluruh dunia. ${ }^{2}$ Berdasarkan Riset Kesehatan Dasar (RISKESDAS) tahun 2013, kasus kanker tertinggi di Indonesia pada laki-laki adalah kanker paru dan kanker kolorektal. ${ }^{3}$ Mortalitas akibat kanker paru menurut hasil penelitian Pusat Deteksi Dini dan Promosi Kesehatan Kementerian Kesehatan Republik Indonesia di Rumah Sakit Kanker Dharmais Jakarta pada tahun 2010 - 2013 adalah cukup tinggi yaitu sebesar 194 kasus. $^{4}$

Hingga saat ini, merokok tembakau merupakan faktor risiko yang paling penting peranannya dalam kanker paru, baik dalam kuantitas maupun rentang waktu merokok. ${ }^{2} \mathrm{Di}$ Indonesia, 59,8 juta orang dewasa merokok tembakau dan 2,9 juta orang dewasa menggunakan produk tembakau bukan rokok. Inisiasi merokok di Indonesia rata-rata pada usia 17,6 tahun. Hal ini membuat Indonesia menjadi salah satu negara yang memiliki jumlah perokok yang cukup tinggi, dan membuat risiko terkena kanker paru semakin tinggi. ${ }^{1}$

Rumah Sakit Immanuel merupakan salah satu institusi pelayanan kesehatan yang menangani kasus kanker paru di kota Bandung. Penelitian ini dilakukan untuk mengetahui gambaran pasien kanker paru di Rumah sakit Immanuel periode Januari 2013 hingga Desember 2014.

\section{Metode}

Metode yang digunakan dalam penelitian ini adalah deskriptif retrospektif dengan pengambilan dan pengumpulan data pasien yang didiagnosis kanker paru yang dirawat inap di Rumah Sakit Immanuel Bandung periode Januari 2013 hingga Desember 2014.Data dianalisis secara deskriptif dan disajikan dalam bentuk tabel distribusi frekuensi.

\section{Hasil}

Berdasarkan data yang diambil dari rekam medis di Rumah Sakit Immanuel Bandung periode Januari 2013 hingga Desember 2014 didapatkan prevalensi kanker paru adalah sebanyak 51 pasien. 
Tabel 1 Gambaran Pasien Kanker Paru Berdasarkan Jenis Kelamin

\begin{tabular}{ccc}
\hline Jenis Kelamin & Frekuensi & Persentase $(\%)$ \\
\hline Laki-laki & 37 & 72,55 \\
Perempuan & 14 & 27,45 \\
\hline Total & 51 & 100 \\
\hline
\end{tabular}

Tabel 1menunjukkan bahwa prevalensi kanker paru di Rumah Sakit Immanuel Bandung periode Januari 2013 hingga Desember 2014 adalah sebesar 51 pasien, 37 pasien (72,55\%) lakilaki, dan 14 pasien $(27,45 \%)$ perempuan, maka jumlah pasien laki-laki lebih besar dibandingkan jumlah pasien perempuan dengan rasio sebesar 2,7:1.

Gambaran pasien kanker paru di Rumah Sakit Immanuel Bandung periode Januari 2013 hingga Desember 2014 berdasarkan usia ditampilkan pada Tabel 2.

Tabel 2 Gambaran Pasien Kanker Paru berdasarkan Usia

\begin{tabular}{ccc}
\hline Usia (tahun) & Frekuensi & Persentase $(\%)$ \\
\hline$<40$ & 1 & 1,96 \\
$41-50$ & 9 & 17,65 \\
$51-60$ & 16 & 31,37 \\
$61-70$ & 20 & 39,21 \\
$>70$ & 5 & 9,8 \\
\hline Total & 51 & 100 \\
\hline
\end{tabular}

Pada Tabel 2 didapatkan hasil kelompok usia tersering untuk pasien kanker paru di Rumah Sakit Immanuel Bandung periode Januari 2013 hingga Desember 2014 adalah kelompok usia 61-70 tahun dengan jumlah 20 pasien $(39,21 \%)$, kemudian diikuti oleh kelompok usia 5160 tahun dengan jumlah 16 pasien $(31,37 \%)$.

Gambaran pasien kanker paru di Rumah Sakit Immanuel Bandung periode Januari 2013 hingga Desember 2014 berdasarkan gejala klinik ditampilkan pada Tabel 3.

Tabel 3 Gambaran Pasien Kanker Paru Berdasarkan Gejala Klinik

\begin{tabular}{ccc}
\hline Gejala Klinik & Frekuensi & Persentase (\%) \\
\hline Sesak Napas & 33 & 64,71 \\
Batuk & 11 & 21,57 \\
Nyeri Kepala & 2 & 3,92 \\
Nyeri Dada & 4 & 7,84 \\
Nyeri Ulu Hati & 2 & 3,92 \\
Mual Muntah & 8 & 5,69 \\
Lemas & 7 & 13,73 \\
Demam & 4 & 7,84 \\
\hline
\end{tabular}


Dari Tabel 3 didapatkan bahwa gejala klinik pasien kanker paru di Rumah Sakit Immanuel Bandung periode Januari 2013 hingga Desember 2014 tersering adalah sesak napas dan batuk. Banyak pasien yang mengalami keluhan yang tidak khas untuk kanker paru, misalnya nyeri kepala, nyeri ulu hati, mual dan muntah, badan lemas, dan demam.

Gambaran pasien kanker paru di Rumah Sakit Immanuel Bandung periode Januari 2013 hingga Desember 2014 berdasarkan metastasis ditampilkan pada Tabel 4.

Tabel 4 Gambaran Pasien Kanker Paru Berdasarkan Metastasis

\begin{tabular}{ccc}
\hline Metastasis Ke & Frekuensi & Persentase (\%) \\
\hline Intrapulmonal & 3 & 5,88 \\
Pleura & 2 & 3,92 \\
Hepar & 8 & 15,69 \\
Serebral & 1 & 1,96 \\
Sumsum Tulang Belakang & 1 & 1,96 \\
Tulang & 1 & 1,96 \\
Tidak Metastasis & 35 & 68,63 \\
\hline Total & 51 & 100
\end{tabular}

Berdasarkan tabel 4 di atas, didapatkan metastasis tersering pada pasien kanker paru di Rumah Sakit Immanuel Bandung periode Januari 2013-Desember 2014 adalah ke hepar sebesar 8 pasien $(15,69 \%)$.

Gambaran pasien kanker paru di Rumah Sakit Immanuel Bandung periode Januari 2013 hingga Desember 2014 berdasarkan persentase kematian ditampilkan pada Tabel 5.

Tabel 5 Gambaran Persentase Kematian Pasien Kanker Paru

\begin{tabular}{ccc}
\hline Keterangan & Frekuensi & Persentase (\%) \\
\hline Hidup & 34 & 66,67 \\
Meninggal & 17 & 33,33 \\
\hline Total & 51 & 100 \\
\hline
\end{tabular}

Tabel 5 menunjukkan persentase kematian pada pasien kanker paru di Rumah Sakit Immanuel Bandung periode Januari 2013 hingga Desember 2014 adalah 33,33\%.

\section{Diskusi}

Dari penelitian ini didapatkan prevalensi kanker paru di Rumah Sakit Immanuel Bandung periode Januari 2013 hingga Desember 2014 adalah sebesar 51 pasien, 37 pasien 


\section{Research Article}

$(72,55 \%)$ laki-laki, dan 14 pasien $(27,45 \%)$ perempuan, maka jumlah pasien laki-laki lebih besar dibandingkan jumlah pasien perempuan dengan rasio sebesar 2,7:1.

Hasil penelitian ini sesuai dengan penelitian World Health Organization melalui program GLOBOCAN 2012 yang mendapatkan bahwa pasien kanker paru laki-laki lebih banyak dibandingkan perempuan, dengan rasio $3: 1 .{ }^{1}$ Penelitian lain yang dilakukan oleh Fakultas Kedokteran Universitas Indonesia pada tahun 2014 di Rumah Sakit Persahabatan Jakarta, juga memberikan hasil yang sesuai dengan hasil penelitian ini, yaitu pasien kanker paru laki-laki $(55,2 \%)$ lebih banyak dibandingkan perempuan $(44,8 \%) .{ }^{5}$ Hasil penelitian ini juga sesuai dengan penelitian yang dilakukan oleh Haryati et al pada tahun 2013 di Rumah Sakit Umum Daerah Ulin Banjarmasin yang mendapatkan pasien kanker paru pada laki-laki lebih banyak dibandingkan perempuan, dengan rasio $3: 1 .^{6}$

Menurut teori, perbandingan yang cukup signifikan antara laki-laki dan perempuan disebabkan karena laki-laki lebih sering memiliki kebiasaan merokok. Rokok mengandung zatzat yang berpotensi menimbulkan gangguan pernapasan dan kanker, terutama kanker paru. ${ }^{6}$

Pada penelitiann ini didapatkan bahwa kelompok usia tersering untuk pasien kanker paru di Rumah Sakit Immanuel Bandung periode Januari 2013 hingga Desember 2014 adalah kelompok usia 61-70 tahun dengan jumlah 20 pasien $(39,21 \%)$, kemudian diikuti oleh kelompok usia 51-60 tahun dengan jumlah 16 pasien $(31,37 \%)$.

Hasil penelitian ini berbeda dari hasil penelitian Haryati et al. pada tahun 2013 yang mendapatkan kelompok usia tersering pasien kanker paru di Rumah Sakit Umum Daerah Ulin Banjarmasin adalah pada usia 51-60 tahun. ${ }^{6}$ Hasil penelitian ini kurang sesuai dengan hasil penelitian Kumar et al. pada tahun 2011 yang mendapatkan sebagian besar pasien kanker paru ditemukan pada kelompok usia 41-60 tahun, kemudian diikuti oleh kelompok usia 61-80 tahun, dan sedikit pada kelompok usia $<40$ tahun. ${ }^{7}$

Insidensi kanker paru meningkat seiring bertambahnya usia. Pajanan-pajanan seperti rokok, radon, silika, dan asbestos diperkirakan menyebabkan perubahan genetik di sel paru, yang terakumulasi dan akhirnya menyebabkan fenotipe neoplastik. ${ }^{8}$ Dengan semakin banyaknya pajanan sejalan dengan pertambahan usia, maka risiko terkena kanker paru akan semakin meningkat. Selain itu, peningkatan umur menyebabkan penurunan imunitas, penurunan perbaikan DNA, dan menyebabkan hilangnya regulasi sel yang memfasilitasi terjadinya karsinogenesis dalam tubuh. ${ }^{6}$

Gejala klinik pasien kanker paru di Rumah Sakit Immanuel Bandung periode Januari 2013 hingga Desember 2014 yang tersering didapatkan adalah sesak napas dan batuk.Hasil penelitian ini sesuai dengan hasil penelitian Haryati et al. pada tahun 2013 yang mendapatkan 


\section{Research Article}

keluhan tersering pada pasien kanker paru adalah sesak napas, sebesar 52,99\%. ${ }^{6}$ Hasil penelitian ini juga sesuai dengan hasil penelitian Kumar et al. di tahun 2011 yang mendapatkan keluhan tersering pada pasien kanker paru adalah batuk $(68,42 \%)$ dan sesak napas $(63,15 \%){ }^{7}$

Gejala klinik sesak napas pada penderita kanker paru dapat disebabkan oleh tumor yang menutupi saluran pernapasan di toraks dan paru-paru atau vena yang membawa darah menuju jantung. Sesak napas dapat juga disebabkan karena adanya cairan berlebih yang memperluas ruangan yang berada di antara lapisan tipis yang melindungi paru dan lapisan tipis yang melindungi dinding toraks (efusi pleura), di antara kantung yang melindungi jantung (efusi perikardial), atau di dalam kavitas abdomen (asites). ${ }^{9}$

Metastasis tersering pada pasien kanker paru di Rumah Sakit Immanuel Bandung periode Januari 2013-Desember 2014 adalah ke hepar sebesar 8 pasien (15,69\%). Hasil penelitian ini kurang sesuai dengan hasil penelitian Riihimaki, et al. yang mendapatkan lokasi metastasis tersering adalah sistem saraf (47\%), tulang (39\%), hepar (35\%), dan sistem pernapasan $(22 \%){ }^{10}$

Proses metastasis kanker memiliki tahapan yang berawal dari sel tumor yang lepas dari matriks ekstraseluler dan menyerang jaringan sekitar. Proteolisis lokal pada membran basalis sel tumor menandakan adanya perubahan dari karsinoma jinak in situ menjadi tumor ganas invasif. Sel tumor akan bermigrasi ke dalam aliran darah vaskuler dengan cara berpenetrasi melalui dinding pembuluh darah yang tipis untuk masuk ke dalam sirkulasi sistemik. ${ }^{11}$

Persentase kematian pada pasien kanker paru di Rumah Sakit Immanuel Bandung periode Januari 2013 hingga Desember 2014 adalah 33,33\%. Hasil penelitian ini tidak banyak berbeda dengan hasil penelitian World Health Organization pada tahun 2012 di Amerika Serikat, bahwa mortalitas akibat kanker paru mencapai angka $29 \%$ untuk pasien laki-laki dan $26 \%$ untuk pasien perempuan. ${ }^{12}$

Kanker paru merupakan salah satu kanker agresif pada manusia, dengan 5-year survival adalah 10-15\%. Pasien dengan stadium kanker IV mempunyai 5-year survival sebesar 2\%, bahkan untuk stadium terendah pun (IA), hanya memiliki 5-year survival sebesar 50\%. Di Amerika Serikat, kanker paru merupakan kanker tersering pada laki-laki maupun perempuan, dengan menyumbang angka sebesar $14 \%$ kasus kanker di setiap jenis kelamin, dan penyebab mortalitas sebesar 29\% pada laki-laki dan 26\% pada perempuan dari angka mortalitas kanker. Prognosis yang buruk dari kanker paru disebabkan karena hampir $80 \%$ pasien terdiagnosis telah mengalami metastasis dan hampir setengah dari jumlah pasien sudah memiliki metastasis jauh. ${ }^{12}$ 


\section{Research Article}

\section{Simpulan}

Simpulan penelitian ini yaitu prevalensi pasien kanker paru periode Januari 2013 hingga Desember 2014 adalah 51 pasien, jenis kelamin laki-laki lebih banyak dibandingkan perempuan dengan ratio 2,7:1, kelompok usia tersering yaitu 61-70 tahun, dengan gejala klinik tersering adalah sesak napas dan batuk, metastasis tersering yaitu ke organ hepar, dan persentase kematian adalah $33,33 \%$.

\section{Daftar Pustaka}

1. International Agency for Research on Cancer World Health Organization. GLOBOCAN 2012: estimated cancer incidence, mortality and prevalence worldwide in 2012. [2012, cited 2015 Jan 21]. Available from: http://globocan.iarc.fr/Pages/fact_sheets_cancer.aspx.

2. American Cancer Society. Cancer facts \&figures 2015.[2015, cited 2015 Jan 8]. Available from: http://www.cancer.org.

3. Badan Penelitian dan Pengembangan Kesehatan Kementrian Kesehatan Republik Indonesia. Riset Kesehatan Dasar 2013. Jakarta; 2013.

4. Kementrian Kesehatan Republik Indonesia. Info DATIN. Pusat Data dan Informasi Kementrian Kesehatan RI. [2015, cited 2015 Jan 5]. Available from: .http://www.depkes.go.id/folder/view/01/structure-publikasipusdatin-info-datin.html.

5. Anwar A, Sjahruddin E, Aniwidyaningsih W, Widyahening IS, Susanto AD. Analisis penyebab kematian pasien kanker paru. Jurnal Respirologi Indonesia. 2014;34:11-6.

6. Haryati, Bakhriansyah M, Aisah SKN. Profil penderita kanker paru primer di Rumah Sakit Umum Daerah Ulin Banjarmasin tahun 2006-2011. Jurnal Respirologi Indonesia. 2013;33:50-6.

7. Kumar BS, Abhijit M, Debasis D, Abinash A, Ghoshal AG, Kumar DS. Clinico-pathological profile of lung cancer in a tertiary medical centre in India: analysis of 266 cases. J Dent Oral Hyg. 2011;3(3):30-3.

8. Kumar V, Abbas AK, Fausto N. Dasar patologis penyakit. Edisi 7. Jakarta: EGC; 2007.

9. National Cancer Institute. Cardiopulmonary syndromes. [2015, cited 2015 Nov 11].Available from: http://www.cancer.gov/about-cancer/treatment/side-effects/cardiopulmonary-pdq\#section/all.

10. Riihimaki M, Hemminki A, Fallah M, Thomsen H, Sundquist K, Sundquist J et al. Metastatic sites and survival in lung cancer. Lung Cancer. 2014;86(1):78-84.

11. Langley RR\& Fidler IJ. The seed and soil hypothesis revisited-The role of tumorstroma interactions in metastasis to different organs. International J Cancer. 2011;128(11):2527-35.

12. World Health Organization. World cancer report 2014. International Agency for Research on Cancer. Geneve: WHO Press; 2014. 